\title{
Systematic Review \\ Electrochemotherapy in Vulvar Cancer and Cisplatin Combined with Electroporation. Systematic Review and In Vitro Studies
}

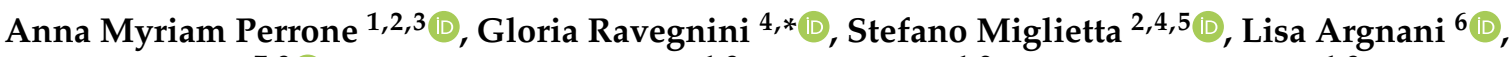 \\ Martina Ferioli 7,8 ${ }^{(0)}$, Eugenia De Crescenzo ${ }^{1,3}$, Marco Tesei 1,2, Marco Di Stanislao ${ }^{1,3}$, Giulia Girolimetti ${ }^{2,3,5}$, \\ Giuseppe Gasparre 2,3,5, Anna Maria Porcelli ${ }^{2,4,5,9}$, Francesca De Terlizzi ${ }^{10}$, Claudio Zamagni ${ }^{2,11}$, \\ Alessio Giuseppe Morganti ${ }^{2,7,8,+}$ and Pierandrea De Iaco ${ }^{1,2,3,+}$
}

check for updates

Citation: Perrone, A.M.; Ravegnini, G.; Miglietta, S.; Argnani, L.; Ferioli, M.; De Crescenzo, E.; Tesei, M.; Di Stanislao, M.; Girolimetti, G.;

Gasparre, G.; et al.

Electrochemotherapy in Vulvar Cancer and Cisplatin Combined with Electroporation. Systematic Review and In Vitro Studies. Cancers 2021, 13, 1993. https://doi.org/10.3390/ cancers13091993

Academic Editors: Giacomo Corrado and Giorgia Garganese

Received: 24 March 2021

Accepted: 19 April 2021

Published: 21 April 2021

Publisher's Note: MDPI stays neutral with regard to jurisdictional claims in published maps and institutional affiliations.

Copyright: (c) 2021 by the authors. Licensee MDPI, Basel, Switzerland. This article is an open access article distributed under the terms and conditions of the Creative Commons Attribution (CC BY) license (https:// creativecommons.org/licenses/by/ $4.0 /)$.
1 Division of Oncologic Gynecology, IRCCS-Azienda Ospedaliero-Universitaria di Bologna, 40138 Bologna, Italy; myriam.perrone@aosp.bo.it (A.M.P.); eugenia.decrescenzo@studio.unibo.it (E.D.C.); marco.tesei@aosp.bo.it (M.T.); marco.distanislao@studio.unibo.it (M.D.S.); pierandrea.deiaco@unibo.it (P.D.I.)

2 Centro di Studio e Ricerca delle Neoplasie Ginecologiche (CSR), University of Bologna, 40138 Bologna, Italy; stefano.miglietta2@unibo.it (S.M.); giulia.girolimetti3@unibo.it (G.G.); giuseppe.gasparre3@unibo.it (G.G.); annamaria.porcelli@unibo.it (A.M.P.); claudio.zamagni@aosp.bo.it (C.Z.); alessio.morganti2@unibo.it (A.G.M.)

3 Department of Medical and Surgical Sciences (DIMEC), University of Bologna, 40138 Bologna, Italy

4 Department of Pharmacy and Biotechnology, University of Bologna, 40126 Bologna, Italy

5 Center for Applied Biomedical Research, Alma Mater Studiorum-University of Bologna, 40138 Bologna, Italy

6 Institute of Hematology, Department of Experimental, Diagnostic and Specialty Medicine, University of Bologna, 40138 Bologna, Italy; lisa.argnani@unibo.it

7 Radiation Oncology, IRCCS Azienda Ospedaliero-Universitaria di Bologna, 40138 Bologna, Italy; martina.ferioli4@unibo.it

8 Department of Experimental, Diagnostic and Specialty Medicine, University of Bologna, 40138 Bologna, Italy

9 Interdepartmental Center for Industrial Research Life Sciences and Technologies for Health, Alma Mater Studiorum-University of Bologna, 40064 Ozzano dell'Emilia, Italy

10 Scientific \& Medical Department IGEA S.p.A., 41012 Carpi, Italy; f.deterlizzi@igeamedical.com

11 Oncologia Medica Addarii, IRCCS Azienda Ospedaliero-Universitaria di Bologna, Via Albertoni 15, 40138 Bologna, Italy

* Correspondence: gloria.ravegnini2@unibo.it

+ Equally contributors.

Simple Summary: Electrochemotherapy (ECT) is an emerging treatment for solid tumors and an attracting research field due to its clinical results. ECT in association with bleomycin is an effective and safe treatment option in the vulvar cancer palliative setting. With regard to cisplatin (CSP)-based ECT, considering the clear evidence on its efficacy in gynecological tumors, the possibility to improve local control with CSP-based ECT is intriguing and a well-designed randomized clinical trial should be addressed to this issue.

Abstract: Electrochemotherapy (ECT) is an emerging treatment for solid tumors and an attractive research field due to its clinical results. This therapy represents an alternative local treatment to the standard ones and is based on the tumor-directed delivery of non-ablative electrical pulses to maximize the action of specific cytotoxic drugs such as cisplatin (CSP) and bleomycin (BLM) and to promote cancer cell death. Nowadays, ECT is mainly recommended as palliative treatment. However, it can be applied to a wide range of superficial cancers, having an impact in preventing or delaying tumor progression and therefore in improving quality of life. In addition, during the natural history of the tumor, early ECT may improve patient outcomes. Our group has extensive clinical and research experience on ECT in vulvar tumors in the palliative setting, with $70 \%$ overall response rate. So far, in most studies, ECT was based on BLM. However, the potential of CSP in this setting seems interesting due to some theoretical advantages. The purpose of this report is to: (i) compare the efficacy of CSP and BLM-based ECT through a systematic literature review; (ii) report the results of our studies on CSP-resistant squamous cell tumors cell lines and the possibility to overcome chemoresistance using ECT; (iii) discuss the future ECT role in gynecological tumors and in particular in vulvar carcinoma. 
Keywords: vulvar cancer; electrochemotherapy; cisplatin; bleomycin

\section{Introduction}

Vulvar carcinoma (VC) is a rare disease ( $5 \%$ of all gynecological neoplasms) with the highest incidence in the elderly, although, in recent years, the spread of human papilloma virus (HPV) infection in young women changed this trend [1]. Squamous cell carcinoma (SCC) is the most frequent histological type ( $90 \%$ of cases), although several rare entities such as melanoma, extra-mammary Paget's disease, Bartholin's gland adenocarcinoma, verrucous carcinoma, basal cell carcinoma (BCC), and sarcoma can occur [2-4]. Surgery is the standard treatment, frequently combined with neoadjuvant chemoradiation; alternatively, the treatment is based on exclusive chemoradiation, based on disease site and patient's performance status [5]. VC is often multifocal and recurs in about one third of cases with 70\% 5-year overall survival rate [5]. When $\mathrm{VC}$ recurs, the therapeutic options are limited also due to the frequently advanced patient's age leading to the frequent referral to palliative care alone. Chemotherapy and radiotherapy have been used in VC symptoms palliation. However, tumor response rates are dismal and data on symptoms relief are almost completely lacking.

Furthermore, radiotherapy has obvious limitations being associated with a nonnegligible incidence and severity of adverse events (AEs), leading to a worse quality of life (QoL). On the contrary, particularly in the palliative setting, treatments effective in terms of local control but without relevant AEs are ideally required. Unfortunately, even surgery and chemotherapy often do not meet this need. In this scenario, some research groups have proposed electrochemotherapy (ECT) to achieve local tumor control and symptoms relief based on the positive results recorded in skin tumors [6-8].

In fact, ECT represents a new therapeutic option of metastatic skin tumors not amenable to surgery or radiotherapy [9]. ECT is based on reversible electroporation (EP) induced by short electrical impulses which increase the permeability of cancer cells membranes to cytotoxic agents. The effect of EP allows drugs with low permeability to concentrate inside the cells, strongly improving their therapeutic efficacy.

In this paper, we summarized the principles of ECT, the mechanism of action of bleomycin (BLM) and cisplatin (CSP), the most frequently drugs combined with $\mathrm{EP}$, and evidence on ECT in VC. Furthermore, we performed a systematic review on CSP-based ECT, reported on the possibility to overcome CSP resistance using EP in SCC cells, and discuss the need and feasibility of a clinical trial aimed to address most unanswered questions on ECT in VC.

\section{Principles of Electrochemotherapy and the New Palliative Care in Vulvar Cancer}

$\mathrm{EP}$ is induced by a train of square wave electrical impulses, with the potential development of pores and their equally rapid disappearance (from few seconds to several minutes) after exposure to the electric field. However, being small and short-lived, the hypothetical pore generation caused by EP has not yet been observed directly, due to the microscale dimension and fragile structure of pores and cells [10,11]. For these reasons, even if evidence seems to suggest that, the pore formation on cell membranes is not completely understood [12]. In general terms, it is accepted that EP promotes structural changes in the cell membrane lipid bilayer which allows higher permeability [13]. This transient condition may be exploited to promote the entry into the cells of non-permeable drugs administered intravenously (IV) or intratumorally [14]. The basic ECT principles are as follows: (1) the peak concentration of chemotherapy in the tumor occurs at the same time of the electrical impulses; (2) the whole tumor mass must be covered by the electric field; (3) to this end, specific electrode sets must be chosen, in terms of depth, size, and shape (plate and needle) [15]. Electrodes may be used as needles arranged in parallel rows, with a 
space of $4 \mathrm{~mm}$ between them (recommended for small nodules), or as needles arranged in a hexagonal manner, ideal for nodules $>1 \mathrm{~cm}[10,15]$. Needles can reach up to $3 \mathrm{~cm}$ depth.

Several drugs have been tested in combination with EP: daunorubicin, doxorubicin, etoposide, paclitaxel, actinomycin D, adriamicin, mitomycin C, 5-fluorouracil, vinblastine, vincristine, gemcitabine, cyclophosphamide, and carboplatin [15]. Currently, the two most frequently used drugs are BLM and CSP. BLM is administered IV $\left(15,000 \mathrm{IU} / \mathrm{m}^{2}\right.$ as a bolus injected in 30-60 s) or intratumorally at the following concentrations: $1000 \mathrm{IU} / \mathrm{cm}^{3}$ for small lesions and $250 \mathrm{IU} / \mathrm{cm}^{3}$ for large lesions [16]. Similarly, also the dose of CSP depends on tumor size, ranging between 0.5 to $2 \mathrm{mg} / \mathrm{cm}^{3}$ [16].

In the above description, we considered only the equipment described in the European Standard Operating Procedures on Electrochemotherapy (ESOPE) procedures although other types of electroporators, needles, drugs and dosages, were described in the literature [17-21].

BLM and CSP have low membrane permeability but after EP, their intracellular concentration increases up to 1000 and 80 fold, respectively (Figure 1) [14].

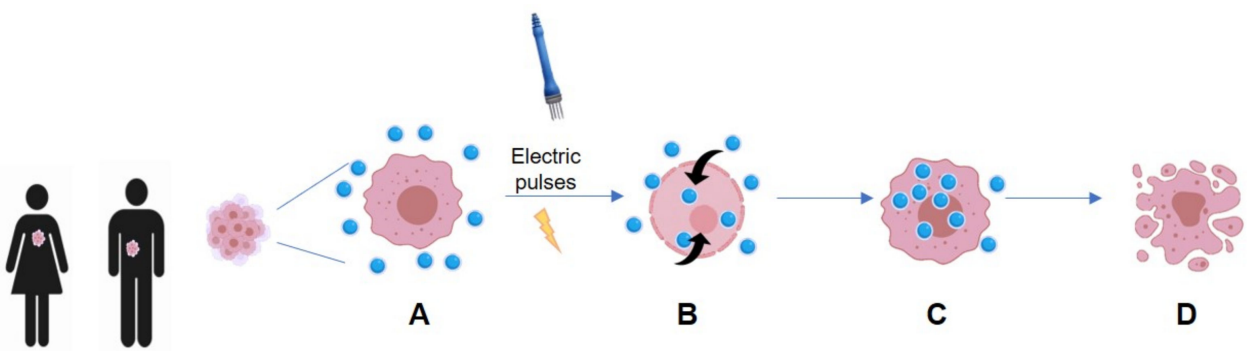

Figure 1. (A) After administration, the drug reaches the tumor cells accumulating outside them, being their entry hindered by the cytoplasmic membrane. (B) Applications of EP promote structural changes in the cell membrane lipid bilayer which allows higher permeability. (C) The drug can enter the cell. (D) The drug can exert its action promoting irreversible damage which causes cell death.

BLM is an antibiotic with anticancer activity which exerts its effect on DNA through a multistep process, although the mechanism of action is unknown in detail. Some data suggest that BLM primarily acts through bonding with metal ions and then formation of metallobleomycin complexes. The latter promotes the generation of reactive oxygen species leading to failure of DNA function by inhibiting DNA, RNA, and protein synthesis [22]. In addition, CSP anti-cancer activity is based on DNA lesions' generation, produced by two different mechanisms: (1) CSP-DNA cross-links inhibit DNA replication and induce cell apoptosis; (2) CSP adducts block RNA elongation and therefore gene transcription, contributing to cell death $[23,24]$. Figure 2 summarizes the main mechanisms involved in ECT response.

At least two other phenomena are involved in enhancing the final ECT antitumor effect: improved immune response and "vascular lock" (Figure 2) [25,26]. With regard to immune response, it has been suggested that the death of electroporated cells could release tumor antigens recognized by the dendritic cells that trigger an adaptive immune anti-cancer response [26-29]. In addition, EP increases the diameter of blood vessels within the tumor and produces constriction of arterioles ending up in the "vascular blockage", which enhances drug trapping and accumulation within the tumor [30]. These mechanisms harm the actively dividing cancer cells more than the non-dividing cells of the surrounding healthy tissue. 


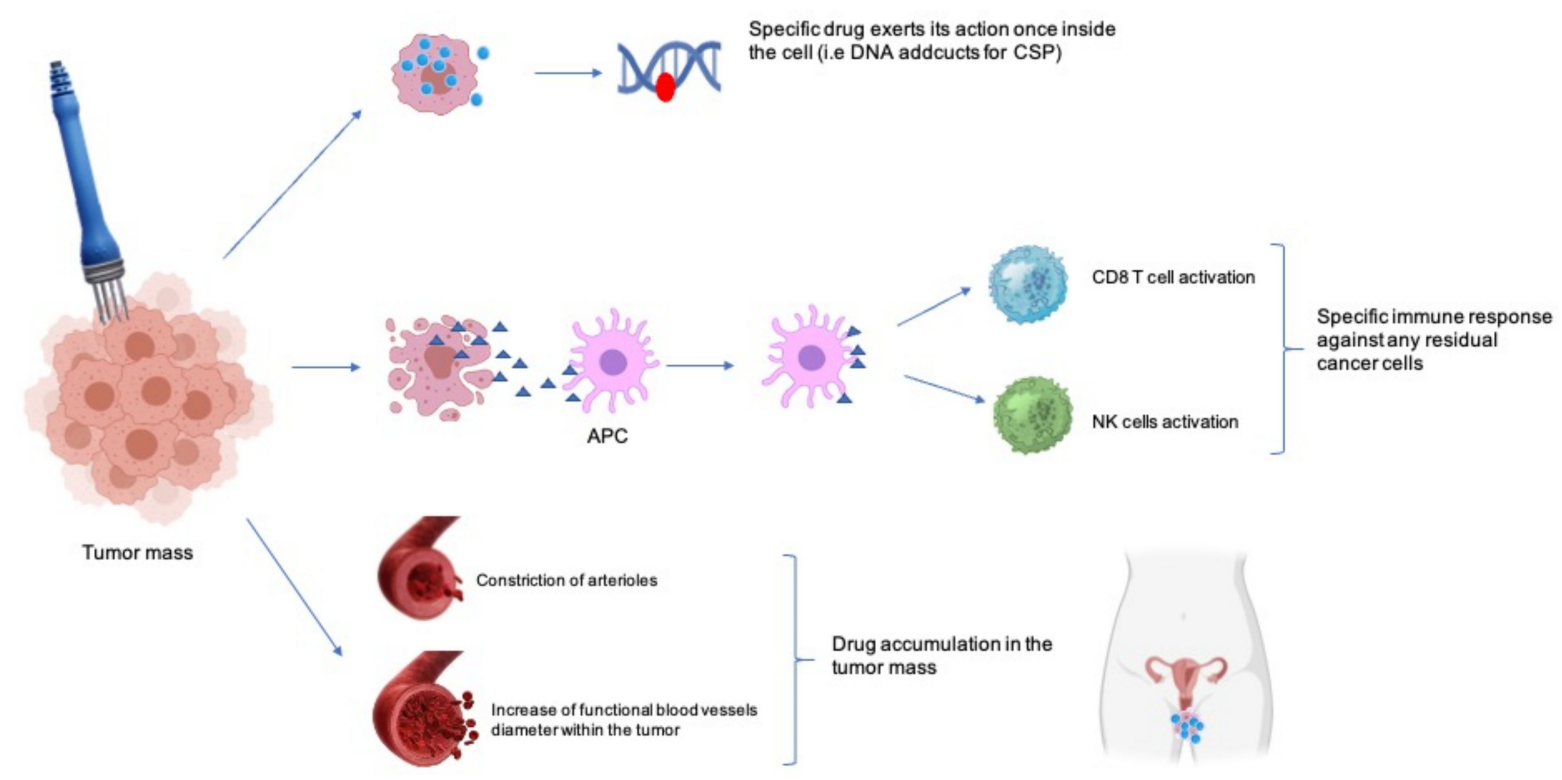

Figure 2. Main mechanisms involved in ECT response: (1) higher drug uptake (higher panel), (2) immunogenic response (middle panel), and (3) vascular lock (lower panel); CSP: cisplatin; APC: antigen presenting cells; NK: natural killer.

In 1993, the first ECT treated tumors, metastatic skin lesions of the head and neck, were described [31]. Over almost 30 years of active research, ECT has been tested and applied in skin metastases from melanoma, breast, and head and neck tumors, and in primary breast, pancreas, colon, and VC [9,32-34]. ECT is currently used as an alternative palliative treatment option after standard therapies to improve patients' QoL. However, the National Institute for Health and Clinical Excellence (NICE) suggests ECT among the possible therapies for: (i) primary BCC and SCC inaccessible or difficult to treat with standard treatments and (ii) skin metastases from non-cutaneous cancers and melanoma [35]. In addition, the German Arbeitsgemeinschaft Dermatologische Onkologie guidelines consider ECT as an alternative treatment of loco-regional relapses from melanoma [36]. Moreover, ECT has been recognized by some national health services for the treatment of skin metastases from various tumors with different histologic types [34]. In 2006, the procedures for ECT have been drawn up by a group of experts, greatly facilitating the introduction and diffusion of this treatment and in 2018, a group of pan-European experts proposed a consensus opinion to update the standard operating procedures based on the gained experience $[37,38]$.

Based on the ECT efficacy in the palliative treatment of skin metastasis, our group published in 2013 the first results on ECT in VC reporting with high local control rates (80\%) and significant symptoms improvement [6]. Subsequently, other groups confirmed our results $[7,39]$. The most frequently treated histologic type was SCC, but data on few cases of melanoma and vulvar Paget's disease were also promising. In 2019, we reported the preliminary results of the ELECHTRA study, currently the largest study on BLM-based ECT in VC patients unsuitable for standard therapies. The study confirmed the positive results in terms of local control (about $80 \%$ ) and therefore we proposed ECT as a viable option in the palliative setting of VC [32]. Based on the available data on 110 patients, the overall response rate (ORR) ranges between $60 \%$ and $83 \%$ in vulvar SCC (Table 1). However, data on QoL were not reported in these studies, while the analyses of this endpoint from the ELECHTRA study have been recently published [40]. Moreover, we treated recurrent and metastatic vaginal tumors with promising results (ORR: 67\%) [41] and we tried to avoid extended surgery in VC using ECT as neoadjuvant therapy. Nevertheless, the results of the last two reports were based on small cohort of patients and therefore, they can be considered just as hypothesis-generating pilot studies. Papers reporting on BLM-based ECT in VC patients are summarized in Table 1. It should be emphasized that only BLMbased ECT was tested in gynecological tumors (GT), although CSP represents the most effective drugs in these cancers. 
Table 1. Studies on bleomycin-based electrochemotherapy in vulvar cancer.

\begin{tabular}{|c|c|c|c|c|c|c|c|c|c|}
\hline \multirow{2}{*}{$\begin{array}{l}\text { Author and Year; } \\
\text { Aim }\end{array}$} & \multirow{2}{*}{$\begin{array}{l}\text { Number of } \\
\text { VC Patients }\end{array}$} & \multirow{2}{*}{ Histology } & \multicolumn{2}{|l|}{ BLM Administration } & \multirow{2}{*}{$\begin{array}{l}\text { Time between } \\
\text { BLM Administration } \\
\text { and EP }\end{array}$} & \multirow{2}{*}{ Electric Field } & \multirow{2}{*}{ Electrodes } & \multirow{2}{*}{ Cliniporator } & \multirow{2}{*}{ Evaluation } \\
\hline & & & Route & Dose & & & & & \\
\hline $\begin{array}{l}\text { Perrone et al., 2013 [6] } \\
\text { Aim: To evaluate safety, local } \\
\text { response, feasibility, and QoL of } \\
\text { EP + BLM. }\end{array}$ & 10 & $\begin{array}{l}9 \mathrm{SCC} \\
(1 \mathrm{pt} \text { lost at FU) }\end{array}$ & $\begin{array}{l}\text { i.v. injected as bolus } \\
(30 \mathrm{~s})\end{array}$ & $\begin{array}{l}15,000 \\
\mathrm{UI} / \mathrm{m}^{2}\end{array}$ & $\begin{array}{l}\text { EP started } 8 \text { min after } \\
\text { bolus and treatment was } \\
\text { completed } 28 \text { min after } \\
\text { infusion end }\end{array}$ & $\begin{array}{l}\text { Pulse delivery } \\
\text { frequency: } 5 \mathrm{kHz} \text { at } \\
\text { a duration of } 100 \mu \mathrm{s} .\end{array}$ & $\begin{array}{l}\text { Type III electrodes placed } \\
\text { into the lesion Electrodes } \\
\text { gently inserted into the skin } \\
\text { of the area affected at a } \\
\text { depth of one centimeter; } \\
\text { procedure repeated to cover } \\
\text { the entire area to be treated. }\end{array}$ & IGEA Italy & $\begin{array}{l}\text { After at least } 4 \\
\text { weeks } \\
\text { CR: } 62.5 \% \\
\text { PR: } 12.5 \% \\
\text { NC: } 12.5 \% \\
\text { PD: } 12.5 \%\end{array}$ \\
\hline $\begin{array}{l}\text { Perrone et al., } 2015 \text { [42] } \\
\text { Aim: To assess tumor response, } \\
\text { symptoms relief, and local tumor } \\
\text { control after EP + BLM }\end{array}$ & 25 & $25 \mathrm{SCC}$ & Same of ref [6] & & Same of ref [6] & Same of ref [6] & Same of ref [6] & IGEA Italy & $\begin{array}{l}\text { OR: } 80 \% \\
\text { CR: } 52 \% \\
\text { PR: } 28 \% \\
\text { SD: } 12 \% \\
\text { PD: } 8 \% \\
\text { After } 4 \text { weeks: local } \\
\text { tumor control 91\% } \\
\text { After 6-months: local } \\
\text { tumor control 53\%, } \\
\text { After 1 year: OS 34\% }\end{array}$ \\
\hline $\begin{array}{l}\text { Pellegrino et al., } 2016 \text { [39] } \\
\text { Aim: To evaluate safety, local } \\
\text { tumor response, and symptoms } \\
\text { relief after ECT }\end{array}$ & 10 & $\begin{array}{l}9 \mathrm{SCC}, \\
1 \text { Paget's }\end{array}$ & $\begin{array}{l}\text { i.v, in a bolus lasting } \\
60-90 \mathrm{~s} \text {. }\end{array}$ & & Same of ref [6] & $\begin{array}{l}\text { Pulse delivery } \\
\text { frequency: } 5 \mathrm{kHz} \text { at } \\
\text { a duration of } 100 \mu \mathrm{s}\end{array}$ & $\begin{array}{l}\text { Electrodes gently inserted } \\
\text { into the skin of the area } \\
\text { affected at a depth of one } \\
\text { centimeter; procedure } \\
\text { repeated to cover the entire } \\
\text { area to be treated. EP } \\
\text { delivered by two types of } \\
\text { needle electrodes (parallel } \\
\text { arrays finger and hexagonal } \\
\text { arrays N-10-HG-10 mm, } \\
\text { suitable for bigger tumors) }\end{array}$ & IGEA Italy & $\begin{array}{l}\text { OR: } 60 \% \\
\text { CR: } 20 \% \\
\text { PR: } 40 \% \\
\text { SD: } 20 \% \\
\text { PD: } 20 \%\end{array}$ \\
\hline $\begin{array}{l}\text { Perrone et al., } 2018 \text { [43] } \\
\text { Aim: To test neo-adjuvant ECT }\end{array}$ & 9 & $9 \mathrm{SCC}$ & Same of ref [6] & & Same of ref [6] & Same of ref [6] & Same of ref $[6]$ & IGEA Italy & $\begin{array}{l}\text { CR: } 11.1 \% \\
\text { PR: } 66.7 \% \\
\text { SD: } 22.2 \% .\end{array}$ \\
\hline $\begin{array}{l}\text { Perrone et al., } 2019 \text { [32] } \\
\text { Aim: To investigate local control } \\
\text { after ECT }\end{array}$ & 61 & $\begin{array}{l}57 \mathrm{SCC} \\
3 \text { Paget's } \\
1 \text { melanoma } \\
\text { Tumor response } \\
\text { evaluated in } 55 \mathrm{pts}\end{array}$ & Same of ref [6] & & Same of ref [6] & Same of ref [6] & Same of ref [6] & IGEA Italy & $\begin{array}{l}\text { After at least } 2 \\
\text { weeks } \\
\text { OR: } 83.6 \% \\
\text { CR: } 52.7 \% \\
\text { PR: } 30.9 \% \\
\text { SD: } 10.9 \% \\
\text { PD: } 1.8 \%\end{array}$ \\
\hline $\begin{array}{l}\text { Corrado et al., } 2020 \text { [7] } \\
\text { Aim: To evaluate clinical outcome } \\
\text { and side effects after ECT }\end{array}$ & 15 & $\begin{array}{l}14 \mathrm{SCC} \\
1 \mathrm{CS}\end{array}$ & Same of ref [6] & & Same of ref $[6]$ & Same of ref $[6]$ & Same of ref $[6]$ & IGEA Italy & $\begin{array}{l}\text { After at least } 4 \\
\text { weeks } \\
\text { CR: } 13.3 \% \\
\text { PR: } 66.6 \% \\
\text { SD: } 13.3 \% \\
\text { PD: } 6.6 \%\end{array}$ \\
\hline
\end{tabular}

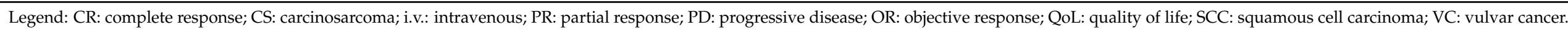




\section{Systematic Review of Studies on Electroporation Combined with Cisplatin}

We performed two systematic reviews. The first aimed to evaluate data available from clinical studies, whereas the second one was focused on in vitro and in vivo studies carried out on GT cell models.

The two systematic reviews were conducted in accordance with the PRISMA Statement principles [44]. PubMed, Web of Knowledge, and Cochrane Library databases were systematically searched for original articles analyzing the efficacy of CSP-based ECT in different cancers (last updated search 1 March 2021). Relevant studies were selected using the Boolean combination of the following key terms: "electrochemotherapy OR ECT" AND "cancer OR tumor OR tumour OR neoplasia OR tumors OR tumours OR cancers" AND "cisplatin OR platin". Additionally, the reference list of reviews, meta-analyses, and all original studies were hand-searched to acquire further relevant studies missed from the initial electronic search.

Eligible studies were required to meet the following inclusion criteria: (i) investigations on CSP-based ECT; (ii) evaluation of the effectiveness of CSP-ECT in human cancer. Exclusion criteria for the first systematic review were: (i) meta-analyses, reviews, and editorials; (ii) non-human cancers; (iii) in vitro studies; (iv) non-English articles. When more than one study had been published sharing part of the same patients' population, only the most recent and complete study was selected. For the second review, based on the above described search strategy, the in vitro and in vivo studies were further analyzed in order to select the ones on GT cell lines (Figure 3).
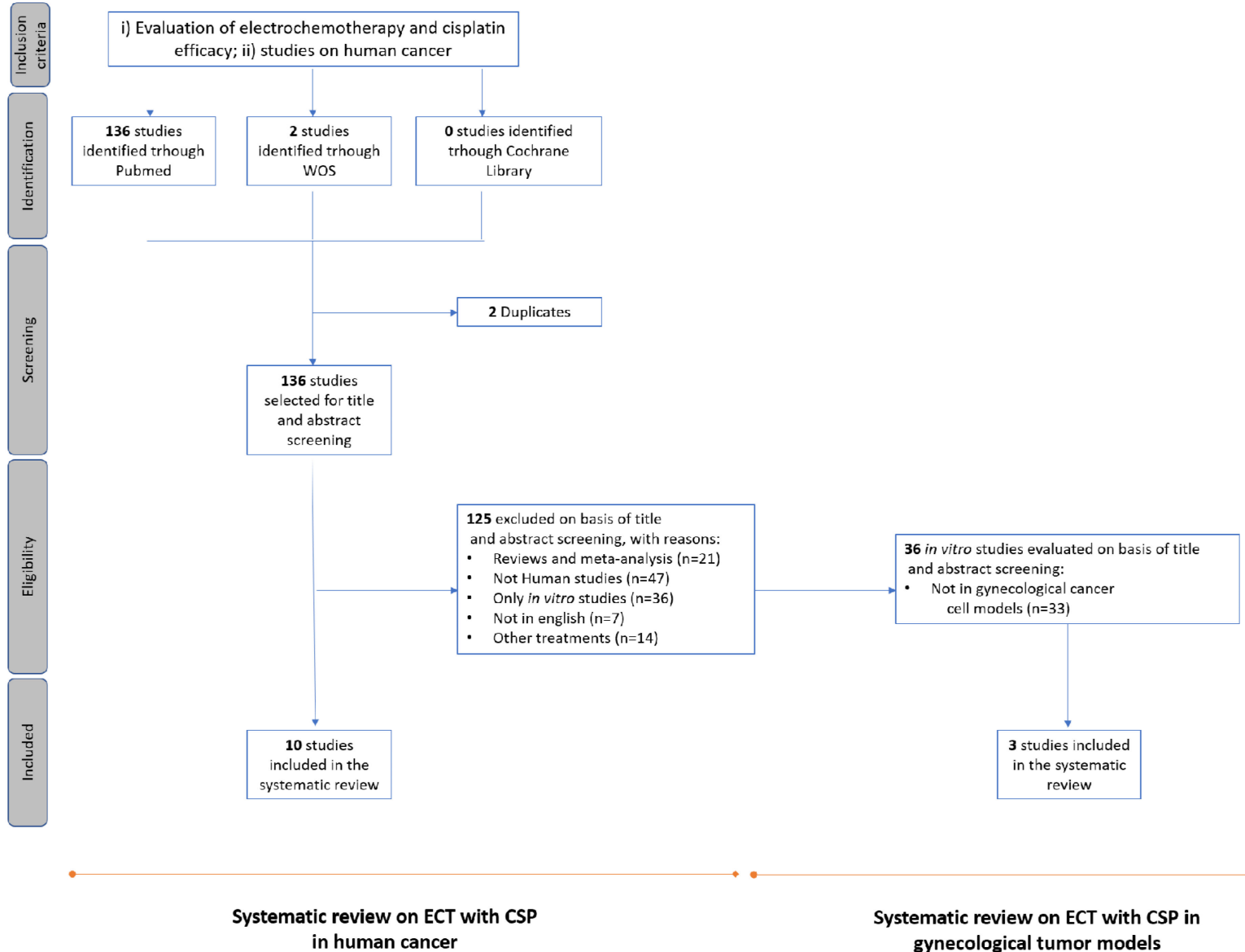

Figure 3. Flowchart of literature search and selection process of eligible studies.

After removing duplicated studies, two investigators (GR and AMP) independently checked titles and abstracts of the retrieved articles and judged their eligibility. Then, the entire text of potentially eligible studies was evaluated to assess appropriateness of 
inclusion in this systematic review. The same two authors independently extracted the following data from the selected papers: (1) first author, publication year, and aim; (2) cancer type, cancer type, sample size; (3) CSP administration route and dose; (4) time between CSP administration and EP; (5) clinical outcome.

From the initial search, we found a total of 138 studies, two of which were duplicated; 125 were excluded based on the inclusion criteria, while 10 were judged adequate for analysis [38,45-53] (Figure 3). The results are summarized in Table 2.

Treated tumors were primary and metastatic skin neoplasms including melanoma, basal cell carcinoma, breast cancer skin metastases, and others. No GTs were included in any of the selected studies. ECT was performed after failure of the conventional treatments as exclusive therapy (seven studies) or in combination with other therapeutic procedures (three studies). CSP was administered intratumorally (1-2 min before EP) except for one study where CSP was administered three hours before EP in order to provide optimal drug concentration in the tumor nodules [46]. In particular, Sersa et al. tested EP in combination with concurrent CSP-based chemoimmunotherapy of the tumor nodules [45], Snoj et al. reported on neoadjuvant CSP-based ECT in one patient with anorectal melanoma [49], while Hribernik et al. evaluated efficacy and safety of EP plus CSP after previous treatment with IFN- $\alpha$ [48]. An intratumoral CSP route of administration was preferred in 9 out of 10 studies. In the Sersa et al. study, the time between CSP injection and EP was at least $3 \mathrm{~h}$ versus $1-2$ min of the intratumoral route.

Most studies were retrospective and included a small number of patients. No randomized controlled trials were retrieved. Overall, the selected studies reported on 423 lesions treated with EP plus CSP, the setting was mainly palliative, and tumor response rates ranged between $40 \%$ and $100 \%$. Retreatment was described in 9 studies (Table 2) and was performed in cases without CR after the first ECT with only one study reporting on repeated ECT after PD [38]. In all retreated cases, a clinical response was recorded, except for only two cases [53]. Regarding the occurrence of PD after repeated ECT, the authors observed that this was a rare occurrence and they concluded that, given the evidence from other studies, their findings should not discourage the combination of CSP and EP.

Generally, response to therapy was assessed 4 weeks after ECT using the Response Evaluation Criteria in Solid Tumors (RECIST). No serious AEs such as edema, ulceration, and depigmentation occurred in the analyzed studies.

Regarding the in vitro and in vivo studies, 36 reports were identified: 33 were excluded because not including GT cell lines while only three studies evaluating EP in GT cell models were selected for the analysis. Effectiveness of EP and CSP in GTs has been so far described by a few reports.

The first evidence dates back to 1998, when Cemazar et al. reported on EP plus CSP in ovarian cancer cells [54]. The aim of this in vitro study was to evaluate the role of EP in promoting CSP efficacy in the characterized human ovarian carcinoma IGROV1cells and their resistant subclone IGROV1/DDP. Both cell lines were treated with CSP alone or in association with EP for an exposure time of $5 \mathrm{~min}$. The results showed that CSP cytotoxicity was significantly potentiated by EP in both cell lines although the IGROV1/DDP subclone exhibited a 50-fold higher resistance. These preliminary results proved that EP enhances CSP activity and cytotoxicity on IGROV1 and IGROV1/DDP cells and paved the way for further investigations. 
Table 2. Studies on cisplatin-based electrochemotherapy.

\begin{tabular}{|c|c|c|c|c|c|c|c|c|c|c|c|c|}
\hline \multirow{2}{*}{$\begin{array}{l}\text { Author and } \\
\text { Year; } \\
\text { Aim }\end{array}$} & \multirow{2}{*}{$\begin{array}{l}\text { Type of } \\
\text { Cancer }\end{array}$} & \multirow{2}{*}{$\begin{array}{l}\text { Number of pts } \\
\text { and Lesions }\end{array}$} & \multirow{2}{*}{$\begin{array}{l}\text { Type of } \\
\text { Sedation }\end{array}$} & \multicolumn{2}{|c|}{ CST Administration } & \multirow{2}{*}{$\begin{array}{l}\text { Time between CSP } \\
\text { Administration } \\
\text { and EP }\end{array}$} & \multirow{2}{*}{ Electric Field } & \multirow{2}{*}{ Electrodes } & \multirow{2}{*}{ Cliniporator } & \multirow{2}{*}{ Evaluation } & \multirow{2}{*}{$\begin{array}{l}\text { Retreatment } \\
\text { with ECT }\end{array}$} & \multirow{2}{*}{ Toxicity } \\
\hline & & & & Route & Dose & & & & & & & \\
\hline $\begin{array}{l}\text { Sersa et al., } \\
1998 \text { [45] } \\
\text { Aim: To assess } \\
\text { response after } \\
\text { EP + CSP. }\end{array}$ & $\begin{array}{l}\text { Malignant } \\
\text { melanoma, } \\
\text { SCC, BCC. }\end{array}$ & $\begin{array}{l}4 \text { pts, } 30 \\
\text { nodules. } \\
19 \text { nodules } \\
\text { treated with } \\
\text { EP and CSP, } 1 \\
\text { with EP, } 5 \text { with } \\
\text { intratumor } \\
\text { CSP, } 5 \text { no } \\
\text { treatment }\end{array}$ & NR & i.t. & $\begin{array}{l}0.25-2 \mathrm{mg} \\
\text { depending on the } \\
\text { size of nodule } \\
\text { Concentration of } 2 \\
\mathrm{mg} / \mathrm{mL} \text { of saline } \\
\text { solution }\end{array}$ & $1-2 \min$ & $\begin{array}{l}\text { Square wave } \\
\text { EO of } 100 \mu \mathrm{s}, \\
910 \mathrm{~V} \\
\text { amplitude } \\
\text { (amplitude to } \\
\text { electrode } \\
\text { distance ratio } \\
1300 \mathrm{~V} / \mathrm{cm} \text { ), } \\
\text { frequency } 1 \\
\text { Hz.: }\end{array}$ & $\begin{array}{l}\text { Two parallel } \\
\text { stainless-steel } \\
\text { electrodes } \\
\text { (thickness } 1 \\
\text { mm; width } 7 \\
\text { mm; length } 14 \\
\text { mm, with } \\
\text { rounded tips } \\
\text { and inner } \\
\text { distance } \\
\text { between them } \\
7 \mathrm{~mm} \text { ) }\end{array}$ & $\begin{array}{l}\text { Jouan GHT } \\
1287 \text { (Jouan, } \\
\text { France). }\end{array}$ & $\begin{array}{l}\text { After at least } 4 \text { weeks } \\
\text { EP + CSP: } \\
\text { CR: } 100 \% \\
\text { CSP alone: } \\
\text { CR: } 40 \% \text {, PD: } 60 \% .\end{array}$ & $\begin{array}{l}\text { In cases } \\
\text { without CR }\end{array}$ & $\begin{array}{l}\text { Mild; } \\
\text { Local }\end{array}$ \\
\hline $\begin{array}{l}\text { Sersa et al., } \\
2000 \text { [47] } \\
\text { Aim: To } \\
\text { evaluate } \\
\text { antitumor } \\
\text { efficacy of EP + } \\
\text { CSP }\end{array}$ & Melanoma & $\begin{array}{l}10 \mathrm{pts}, 133 \\
\text { nodules. } \\
82 \text { nodules } \\
\text { treated with } \\
\text { EP and CSP, } 27 \\
\text { treated with } \\
\text { CSP, } 2 \text { treated } \\
\text { with EP, } 22 \\
\text { untreated. }\end{array}$ & NR & i.t. & Same of ref [45] & $1-2 \mathrm{~min}$. & $\begin{array}{l}\text { Same of ref } \\
{[45]}\end{array}$ & $\begin{array}{l}\text { Same of ref } \\
{[45]}\end{array}$ & $\begin{array}{l}\text { Same of ref } \\
{[45]}\end{array}$ & $\begin{array}{l}\text { After at least } 4 \text { weeks } \\
\text { EP + CSP: } \\
\text { OR: 78\%; CR: 68\%; PR: } \\
\text { 10\%; PD: 7\%; NC: } \\
\text { 15\%. } \\
\text { CSP alone: OR: } 38 \% \text {, } \\
\text { CR: } 19 \% \text {; PR: } 19 \% \text {. PD: } \\
33 \% \text {, NC: } 30 \% . \\
\text { EP alone; } \\
\text { PD: } 50 \% ; \text { PR: 50\% } \\
\text { UT nodules PD: } 64 \% \text {; } \\
\text { NC: } 36 \%\end{array}$ & $\begin{array}{l}\text { In case of not } \\
C R\end{array}$ & $\begin{array}{l}\text { Mild; } \\
\text { Local }\end{array}$ \\
\hline $\begin{array}{l}\text { Sersa et al., } \\
2000[46] \\
\text { Aim: To } \\
\text { evaluate the } \\
\text { effectiveness } \\
\text { EP + CSP }\end{array}$ & $\begin{array}{l}\text { Skin } \\
\text { metastases } \\
\text { from } \\
\text { malignant } \\
\text { melanoma }\end{array}$ & $\begin{array}{l}9 \text { pts, } 27 \\
\text { lesions } \\
\text { vs } 18 \text { lesions }\end{array}$ & NR & i.v. & $\begin{array}{l}\text { Vinblastine }(4 \\
\left.\mathrm{mg} / \mathrm{m}^{2}\right) \text {, oral } \\
\text { lomustine }(80 \\
\left.\mathrm{mg} / \mathrm{m}^{2}\right) \text { on Day } 1, \\
\text { intravenous } \\
\text { cisplatin }(20 \\
\left.\mathrm{mg} / \mathrm{m}^{2}\right) \text { on Days } 2 \\
\pm 5, \text { and } \\
\text { interferon- } 2 \mathrm{~b} 3 \\
\mathrm{mg} / \mathrm{m}^{2} \text { on Days } \\
4-7\end{array}$ & $\begin{array}{l}\text { At least } 3 \mathrm{~h} \text { after the } \\
\text { infusion start. } \\
\text { EP performed on } \\
\text { day } 4 \text { of chemoim- } \\
\text { munotherapy } \\
\text { protocol and the } \\
\text { same day of the } \\
\text { CSP administration } \\
\text { during the daily } \\
\text { chemotherapy }\end{array}$ & $\begin{array}{l}1300 \mathrm{~V} / \mathrm{cm}, 8 \\
\text { pulses, } 99 \mu \mathrm{s}, 1 \\
\mathrm{~Hz}\end{array}$ & & & $\begin{array}{l}\text { After at least } 4 \text { weeks, } \\
\text { EP + CSP: } \\
\text { OR: } 48 \% \\
\text { CR: } 11 \% \\
\text { PR: } 37 \% \\
\text { NC: } 40.7 \% \\
\text { PD: } 11.1 \% \\
\text { Vinblastin alone: } \\
\text { OR: } 22 \% \\
\text { CR: } 11.1 \% \\
\text { PR: } 11.1 \% \\
\text { NC: } 38.9 \% \\
\text { PD: } 38.9 \%\end{array}$ & In case of PD & $\begin{array}{l}\text { Mild; } \\
\text { Local }\end{array}$ \\
\hline
\end{tabular}


Table 2. Cont

\begin{tabular}{|c|c|c|c|c|c|c|c|c|c|c|c|c|}
\hline \multirow{2}{*}{$\begin{array}{l}\text { Author and } \\
\text { Year; } \\
\text { Aim }\end{array}$} & \multirow{2}{*}{$\begin{array}{l}\text { Type of } \\
\text { Cancer }\end{array}$} & \multirow{2}{*}{$\begin{array}{l}\text { Number of pts } \\
\text { and Lesions }\end{array}$} & \multirow{2}{*}{$\begin{array}{l}\text { Type of } \\
\text { Sedation }\end{array}$} & \multicolumn{2}{|c|}{ CST Administration } & \multirow{2}{*}{$\begin{array}{l}\text { Time between CSP } \\
\text { Administration } \\
\text { and EP }\end{array}$} & \multirow{2}{*}{ Electric Field } & \multirow{2}{*}{ Electrodes } & \multirow{2}{*}{ Cliniporator } & \multirow{2}{*}{ Evaluation } & \multirow{2}{*}{$\begin{array}{l}\text { Retreatment } \\
\text { with ECT }\end{array}$} & \multirow{2}{*}{ Toxicity } \\
\hline & & & & Route & Dose & & & & & & & \\
\hline $\begin{array}{l}\text { Sersa et al., } \\
2003 \text { [52] } \\
\text { Aim: To } \\
\text { evaluate } \\
\text { efficacy of EP + } \\
\text { CSP }\end{array}$ & $\begin{array}{l}\text { Malignant } \\
\text { melanoma }\end{array}$ & $\begin{array}{l}14 \text { pts, } 211 \\
\text { lesions }\end{array}$ & NR & i.t. & $1 \mathrm{mg} / \mathrm{cm}^{3}$ & NA & $\begin{array}{l}\text { Square wave } \\
100 \mu s, 910 \mathrm{~V} \\
\text { amplitude } \\
\text { (amplitude to } \\
\text { electrode } \\
\text { distance ratio } \\
1300 \mathrm{~V} / \mathrm{cm} \text { ), } \\
\text { frequency } 1 \\
\mathrm{~Hz} ;\end{array}$ & $\begin{array}{l}\text { Two parallel } \\
\text { stainless-steel } \\
\text { electrodes } \\
\text { (thickness } 1 \\
\mathrm{~mm} \text {; width } 7 \\
\mathrm{~mm} \text {; length } 14 \\
\mathrm{~mm} \text {, with } \\
\text { rounded tips } \\
\text { and inner } \\
\text { distance } \\
\text { between them } \\
7 \mathrm{~mm} \text { ) }\end{array}$ & $\begin{array}{l}\text { Same of ref } \\
\text { [45] }\end{array}$ & $\begin{array}{l}\text { After at least } 4 \text { weeks } \\
\text { OR: } 82 \% \\
\text { CR: } 70.1 \% \\
\text { PR: } 10.9 \% \\
\text { NC: } 11.4 \% \\
\text { PD: } 7.6 \%\end{array}$ & $\begin{array}{l}\text { In cases with } \\
\text { no CR }\end{array}$ & $\begin{array}{l}\text { Mild; } \\
\text { Local }\end{array}$ \\
\hline $\begin{array}{l}\text { Rebersek et al., } \\
2004 \text { [51] } \\
\text { Aim: To } \\
\text { evaluate } \\
\text { efficacy of EP + } \\
\text { CSP }\end{array}$ & $\begin{array}{l}\text { Metastatic } \\
\text { breast cancer } \\
\text { Prior standard } \\
\text { treatment or } \\
\text { refused other } \\
\text { standard } \\
\text { treatments. }\end{array}$ & $\begin{array}{l}6 \text { pts with } 26 \\
\text { cutaneous } \\
\text { lesions. } \\
12 \text { lesions } \\
\text { treated with } \\
\text { EP + CSP and } \\
6 \text { with CSP } \\
\text { alone; } 8 \\
\text { untreated }\end{array}$ & LA & i.t. & Same of ref [45] & $1-2 \mathrm{~min}$. & $\begin{array}{l}\text { Square wave } \\
\text { EP locally on } \\
\text { cutaneous } \\
\text { tumor lesions; }\end{array}$ & $\begin{array}{l}\text { Two superficial } \\
\text { plate } \\
\text { electrodes } \\
\text { (thickness } 1 \\
\mathrm{~mm} \text {, width } 7 \\
\mathrm{~mm} \text {, length } 14 \\
\mathrm{~mm} \text {, inner } \\
\text { distance } \\
\text { between them } \\
7 \mathrm{~mm} \text { ). EP } \\
\text { amplitude } 910 \\
\mathrm{~V} \text {, duration } 100 \\
\mu \mathrm{s} \text {, and } \\
\text { frequency } 1 \mathrm{~Hz}\end{array}$ & $\begin{array}{l}\text { GHT } 1287 \\
\text { (Jouan, France). } \\
\text { In lesions > } 7 \\
\text { mm, treatment } \\
\text { performed in } \\
\text { several EP } \\
\text { runs with } \\
\text { electrodes } \\
\text { repositioning }\end{array}$ & $\begin{array}{l}\text { after at least } 4 \text { weeks } \\
\text { EP + CSP treated } \\
\text { lesions } \\
\text { OR: } 100 \% \text { CR: } 33 \% \text {; } \\
\text { PR: } 67 \% \\
\text { CSP alone treated } \\
\text { group } \\
\text { PR: } 83 \% \\
\text { PD: } 17 \% \\
\text { UT nodules } \\
\text { PD: } 75 \% \text {; NC: 25\% }\end{array}$ & $\begin{array}{l}\text { In cases with } \\
\text { no } C R\end{array}$ & $\begin{array}{l}\text { Mild, } \\
\text { Local }\end{array}$ \\
\hline $\begin{array}{l}\text { Snoj et al., } \\
2005 \text { [49] } \\
\text { Aim: To } \\
\text { evaluate } \\
\text { achievement of } \\
\text { local sphincter- } \\
\text { saving } \\
\text { excision }\end{array}$ & $\begin{array}{l}\text { Anorectal } \\
\text { malignant } \\
\text { melanoma }\end{array}$ & $1 \mathrm{pt}, 1$ lesion & GA & i.t. & $\begin{array}{l}\text { Total dose of } 6 \mathrm{mg} \\
\text { Concentration of } 2 \\
\mathrm{mg} / \mathrm{mL} \text { of } \mathrm{H} 20\end{array}$ & $2-5 \mathrm{~min}$ & $\begin{array}{l}\text { ELECTRIC } \\
\text { FIELD: At each } \\
\text { application } 8 \\
\text { EP } 730 \mathrm{~V} \text { and } \\
100 \mu \mathrm{s} \\
\text { duration } \\
\text { delivered at a } \\
\text { frequency of } 5 \\
\text { kHz between } \\
\text { each pair of } \\
\text { neighboring } \\
\text { electrodes ( } 8 \\
\text { mm apart). } \\
\text { Thus, } 192 \mathrm{EP} \\
\text { delivered at } \\
\text { each } \\
\text { application }\end{array}$ & & & $\begin{array}{l}\text { after at least } 4 \text { weeks } \\
\text { PR }\left(\mathrm{from}^{3} 6.2 \mathrm{~cm}^{3} \text { to }\right. \\
\left.3.8 \mathrm{~cm}^{3}\right)\end{array}$ & yes & NR \\
\hline
\end{tabular}


Table 2. Cont.

\begin{tabular}{|c|c|c|c|c|c|c|c|c|c|c|c|c|}
\hline \multirow{2}{*}{$\begin{array}{l}\text { Author and } \\
\text { Year; } \\
\text { Aim } \\
\end{array}$} & \multirow{2}{*}{$\begin{array}{l}\text { Type of } \\
\text { Cancer }\end{array}$} & \multirow{2}{*}{$\begin{array}{l}\text { Number of pts } \\
\text { and Lesions }\end{array}$} & \multirow{2}{*}{$\begin{array}{l}\text { Type of } \\
\text { Sedation }\end{array}$} & \multicolumn{2}{|c|}{ CST Administration } & \multirow{2}{*}{$\begin{array}{l}\text { Time between CSP } \\
\text { Administration } \\
\text { and EP }\end{array}$} & \multirow{2}{*}{ Electric Field } & \multirow{2}{*}{ Electrodes } & \multirow{2}{*}{ Cliniporator } & \multirow{2}{*}{ Evaluation } & \multirow{2}{*}{$\begin{array}{l}\text { Retreatment } \\
\text { with ECT }\end{array}$} & \multirow{2}{*}{ Toxicity } \\
\hline & & & & Route & Dose & & & & & & & \\
\hline $\begin{array}{l}\text { Marty M, et al., } \\
2006 \text { [38] } \\
\text { Aim: To } \\
\text { evaluate } \\
\text { efficacy and } \\
\text { safety of BLM- } \\
\text { and CSP-based } \\
\text { ECT }\end{array}$ & $\begin{array}{l}\text { Skin and } \\
\text { subcutaneous } \\
\text { metastases } \\
\text { from } \\
\text { malignant } \\
\text { melanoma } \\
\text { carcinoma and } \\
\text { sarcoma }\end{array}$ & $\begin{array}{l}44 \text { lesions } \\
\text { Part of a larger } \\
\text { study } \\
\text { including a } \\
\text { total of } 41 \text { pts } \\
\text { and } 171 \text { lesions } \\
\text { treated with } \\
\text { EP + BLM or } \\
\text { EP + CSP }\end{array}$ & GA or LA & i.t. & $\begin{array}{l}0.5-2 \mathrm{mg} / \mathrm{cm}^{3} \text { of } \\
\text { tissue }\end{array}$ & Within 2 min & $\begin{array}{l}1300 \mathrm{~V} / \mathrm{cm}, 8 \\
\text { pulses, } 100 \mu \mathrm{s}, \\
1 \text { or } 5000 \mathrm{~Hz} \\
\text { (type I), } 1000 \\
\mathrm{~V} / \mathrm{cm}, 8 \text { pulses, } \\
100 \mu \mathrm{s}, 1 \text { or } \\
5000 \mathrm{~Hz}(\mathrm{type} \\
\mathrm{II}), 1000 \mathrm{~V} / \mathrm{cm}, \\
96 \mathrm{pulses}, \\
100 \mu \mathrm{s}, 5000 \\
\mathrm{~Hz} \text { (type III) }\end{array}$ & $\begin{array}{l}\text { Type I, II and } \\
\text { III electrodes }\end{array}$ & & $\begin{array}{l}\text { after at least } 4 \text { weeks } \\
\text { CR: } 75.4 \%\end{array}$ & In case of PD & $\begin{array}{l}\text { Mild, } \\
\text { Local }\end{array}$ \\
\hline $\begin{array}{l}\text { Campana L } \\
\text { et al., 2014 [53] } \\
\text { Aim: To } \\
\text { evaluate ECT } \\
\text { efficacy and } \\
\text { safety }\end{array}$ & SCC & $\begin{array}{l}2 \text { pts; } \\
\text { Number of } \\
\text { lesions not } \\
\text { reported } \\
\text { Comparison } \\
\text { with BLM } \\
\text { alone }\end{array}$ & GA & i.t & $\begin{array}{l}0.5-2 \mathrm{mg} / \mathrm{cm}^{3} \text { of } \\
\text { tissue }\end{array}$ & NA & $\begin{array}{l}8 \text { pulses, } 100 \\
\mu \mathrm{s}, 5000 \mathrm{~Hz} \text {. } \\
960 \mathrm{~V} ;\end{array}$ & $\begin{array}{l}\text { Two plate } \\
\text { electrodes }\end{array}$ & IGEA, Italy & $\begin{array}{l}\text { after at least } 4 \text { weeks } \\
\text { SD 50\% } \\
\text { PD: } 50 \%\end{array}$ & Not performed & $\begin{array}{l}\text { Mild, } \\
\text { Local }\end{array}$ \\
\hline $\begin{array}{l}\text { Hribernik } \\
\text { et al., 2016 [48] } \\
\text { Aim: To } \\
\text { evaluate ECT } \\
\text { after treatment } \\
\text { with IFN- } \alpha\end{array}$ & $\begin{array}{l}\text { Cutaneous } \\
\text { melanoma }\end{array}$ & $\begin{array}{l}2 \text { pts, } 3 \text { lesions } \\
\text { Part of a larger } \\
\text { study } \\
\text { including a } \\
\text { total of 5 pts, } \\
111 \text { lesions } \\
\text { treated with } \\
\text { EP + BLM or } \\
\text { EP + CSP } \\
\end{array}$ & GA or LA & i.t. & Same of ref [45] & Within 2 min & $\begin{array}{l}1300 \mathrm{~V} / \mathrm{cm}, 8 \\
\text { pulses, } 99 \mu \mathrm{s}, 1 \\
\mathrm{~Hz}\end{array}$ & & & $\begin{array}{l}\text { after at least } 4 \text { weeks } \\
\text { CR: } 100 \%\end{array}$ & $\begin{array}{l}\text { In cases with } \\
\text { no CR }\end{array}$ & NR \\
\hline $\begin{array}{l}\text { De Giorgi et al., } \\
\text { 2020 [50] } \\
\text { Aim: To } \\
\text { evaluate } \\
\text { EP+CSP } \\
\text { efficacy and } \\
\text { patients' } \\
\text { tolerability }\end{array}$ & $\begin{array}{l}\text { SCC, BCC, or } \\
\text { skin } \\
\text { metastases } \\
\text { from cancer } \\
\text { other than } \\
\text { melanoma }\end{array}$ & $\begin{array}{l}8 \text { pts, } 18 \\
\text { lesions } \\
\text { (3 SCC, } 4 \text { BCC, } \\
1 \text { skin } \\
\text { metastases } \\
\text { from breast } \\
\text { cancer) }\end{array}$ & GA & i.t. & $\begin{array}{l}\text { Total dose at least } \\
0.441 \mathrm{~mL} \text { for each } \\
\text { treated lesion. } \\
\text { Concentration at } \\
\text { least } 1 \mathrm{mg} / \mathrm{mL}\end{array}$ & Within few minutes & $\begin{array}{l}1000 \mathrm{~V} / \mathrm{cm} \\
\text { and } 100 \mu \text { s the } \\
\text { pulse duration; } \\
3.8 \text { pulses for } \\
\text { each pulse } \\
\text { delivering }\end{array}$ & $\begin{array}{l}\text { Linear lamellar } \\
\text { electrode } \\
\text { (P-30-8B), } \\
\text { finger } \\
\text { electrodes } \\
\text { (F-10-OR) or } \\
\text { linear } \\
\text { electrodes } \\
\text { (N20-4B) were } \\
\text { used }\end{array}$ & EPS02 model & $\begin{array}{l}\text { after at least } 8 \text { weeks } \\
\text { CR: } 50 \% \\
\text { PR: } 50 \% \\
\text { ORR: } 100 \%\end{array}$ & $\begin{array}{l}\text { In cases with } \\
\text { no } \mathrm{CR}\end{array}$ & $\begin{array}{l}\text { Mild, } \\
\text { Local }\end{array}$ \\
\hline
\end{tabular}

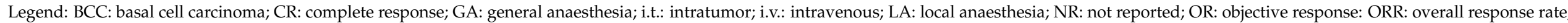
PR: partial response; PD: progressive disease; SCC: squamous cell carcinoma; UT: untreated. 
A subsequent study investigated the cytotoxic effect of 5-fluorouracil and CSP on two human ovarian cancer cell lines, OvBH-1 and SKOV-3, and EP ability to reduce the effective drug dose [55]. The authors reported that EP with CSP showed a major enhancement in drug transport and in cytotoxic activity in both cell lines. This result is very interesting because both cell lines were CSP-resistant, which, as mentioned, is a largely common circumstance in ovarian cancer chemotherapy. In fact, resistance is a main issue in CSP-based chemotherapy and identification of novel drug delivery systems remains an unmet clinical need.

Recently, Łapinska et al. further analyzed the role of CSP-based ECT in ovarian cancer in combination with estradiol [56]. Indeed, it is well known that the biological mechanisms of ovarian cancer development and progression are tightly linked to estrogen hormones. Estrogens exert a direct action on ovarian cells that may promote tumor development, e.g., producing DNA damage due to enhanced proliferation; $17 \beta$-estradiol is usually overexpressed in ovarian cancer patients, but its role is not completely clear. The authors aimed to evaluate $17 \beta$-estradiol effect in combination with ECT and CSP in ovarian cancer cells. The MDAH-2774 cell line was used. EP was first evaluated alone (using 3 different protocols) and then by adding CSP with or without a preincubation with $17 \beta$-estradiol. EP alone achieved a strong cytotoxic effect with $50 \%$ reduction in cell viability while CSP addition enhanced this effect. Electroporated cells, irrespective of the protocol, when pre-incubated with $17 \beta$-estradiol, showed reduced mitochondrial activity, which was used as a surrogate of cell viability. At the same time, the authors highlighted that estradiol reduced EP effectiveness, suggesting the existence of other mechanisms not related to changes in the cell membrane permeability.

Our review shows the lack of in vivo studies and that the in vitro analyses have been so far performed only on ovarian cancer cells; we did not find studies on squamous cell carcinoma cells which is the most frequent GT histologic types. However, all reported in vitro studies have shown an enhanced EP therapeutic effect by combination with CSP, confirming the potential effectiveness of this drug in the ECT setting.

\section{Electroporation Increased the Sensitivity to Cisplatin of Uterine Cervical Chemoresistant Cancer Cells}

In order to test if EP is able to overcome platinum resistance in SCC human cervical cancer, CSP-sensitive 2008 cell line and its syngeneic CSP-resistant C13 cell line (generated by growth in $1 \mathrm{mM} \mathrm{CSP}$ for 13 months) were used. Both cell lines were grown in RPMI 1640 medium, supplemented with $10 \%$ fetal bovine serum, $2 \mathrm{mmol} / \mathrm{L}$ L-glutamine, 100 units $/ \mathrm{mL}$ penicillin, and $100 \mathrm{mg} / \mathrm{mL}$ streptomycin in a humidified incubator at $37{ }^{\circ} \mathrm{C}$ with $5 \% \mathrm{CO}_{2}$.

When 2008 and $\mathrm{C} 13$ cancer cells reached $70 \%$ confluence, they were harvested with $0.5 \%$ trypsin, counted, and resuspended in medium $\left(1 \times 10^{6}\right.$ cells $\left./ \mathrm{mL}\right)$. A volume of $200 \mu \mathrm{L}$ of cell suspension was placed in an EP cuvette with $0.2 \mathrm{~cm}$ gap between the electrodes (SigmaAldrich, St. Louis, MO, USA). CSP (Accord Healthcare) was added to 2008 and C13 cell suspensions at different concentrations $(0.5,1,2,4,8,16 \mu \mathrm{M})$. Cuvettes with CSP-treated cells were placed in the Cliniporator ${ }^{\circledR}$ (IGEA S.p.A) and ECT was performed following pre-set parameters ( $400 \mathrm{~V}, 8$ pulses, $100 \mu \mathrm{s})$. The EP efficiency was evaluated by counting cells stained with trypan blue dye and then cell suspensions were incubated at $37^{\circ} \mathrm{C}$ and $5 \% \mathrm{CO}_{2}$ for 30 min. Subsequently, cell suspensions were diluted (1:10) and seeded in 24-wells plates. In parallel, non-electroporated cells were seeded as negative control. Furthermore, the basal effect of CSP in chemoresistant and chemosensitive cell lines was evaluated by measuring cell viability after $72 \mathrm{~h}$ of treatment with different drug concentrations.

Cell viability was assessed by using sulforhodamine B (SRB), an anionic dye which forms electrostatic complexes with basic protein residues in acid conditions. At the end of each treatment time, cells were fixed with $50 \%$ trichloroacetic acid for $1 \mathrm{~h}$ at $4{ }^{\circ} \mathrm{C}$, washed 5 times with water, and dried at room temperature. Attached cells were stained for $30 \mathrm{~min}$ with $0.4 \%$ SRB diluted in $1 \%$ acetic acid at room temperature. Subsequently, cells were washed 4 times with $1 \%$ acetic acid in order to remove the excess of dye. The dye bound to the cells was finally solubilized with $10 \mathrm{mM}$ Tris ( $\mathrm{pH} \mathrm{10.5)} \mathrm{and} \mathrm{the} \mathrm{relative} \mathrm{absorbance} \mathrm{of}$ 
SRB was detected using a plate reader (VICTOR3 1420 Multilabel Counter-PerkinElmer, Turku, Finland) at the wavelength of $560 \mathrm{~nm}$.

In order to evaluate the in vitro effect of EP combined with cisplatin, we used CSPsensitive 2008 cervical cancer cell line and its syngeneic chemoresistant C13 counterpart. The effect of different CSP concentrations was determined in terms of cell viability (Figure 4A), confirming a higher CSP-related half-maximal effective concentration (EC50) in the chemoresistant cell line compared to the sensitive counterpart (Figure 4B). Moreover, we ruled out a possible effect of EP alone, at the conditions we used, on cell viability unrelated to cisplatin, on both cell lines (Figure 4C). We next proceeded to test if the CSP cytotoxic effects could be boosted through EP, and to this aim, we tested increasing drug concentrations: the viability of both cell lines was significantly reduced by ECT, in a CSP dose-dependent manner (Figure 4D). Interestingly, the effect of ECT was more prominent in the CSP-chemoresistant cell line.

A

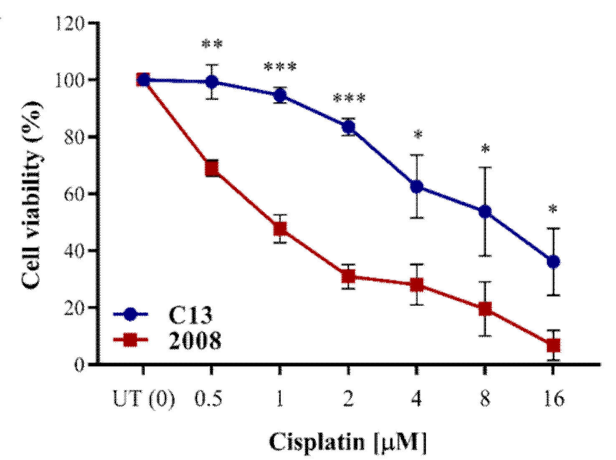

B

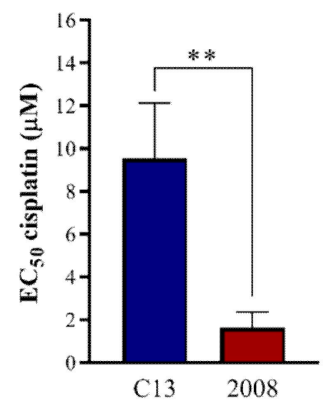

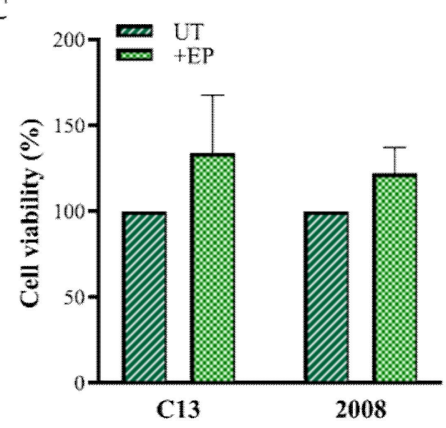

D

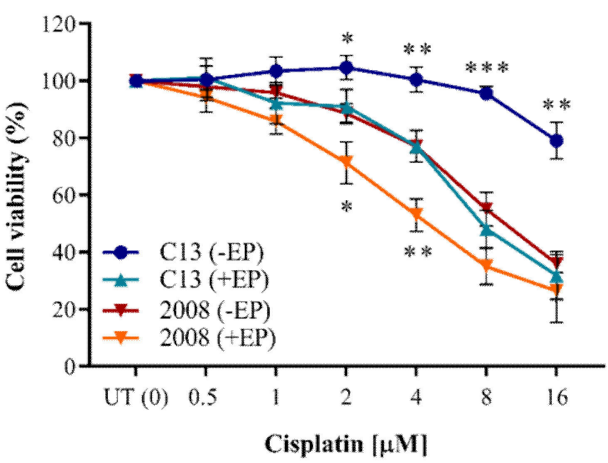

Figure 4. (A) Cell viability of $\mathrm{C} 13$ and 2008 cancer cell lines after $72 \mathrm{~h}$ of treatment with different CSP concentrations. Data are mean \pm SD $(n=3)$. (B) CSP EC50 in C13 and 2008 cell lines calculated after $72 \mathrm{~h}$ of treatment. EC50 indicates the CSP concentration that results in a $50 \%$ decrease of cells viability. Data are mean $\pm S D(n=3)$. (C) Cell viability of $\mathrm{C} 13$ and 2008 cancer cell lines after $72 \mathrm{~h}$ from the EP performed at $400 \mathrm{~V}$, with 8 pulses in $100 \mu$ s. Data (mean $\pm \mathrm{SD} ; \mathrm{n}=3$ ) were normalized to the cell viability of non-electroporated cells (UT) reported as 100\%. C13 UT vs EP C13: $p>0.05$; 2008 UT vs EP 2008: $p>0.05$. (D) Cell viability of C13 and 2008 cancer cell lines after $72 \mathrm{~h}$ from EP treatment, using increasing CSP concentration in combination or not with EP $( \pm \mathrm{EP})$. Data (mean \pm $\mathrm{SD} ; \mathrm{n}=3$ ) were normalized on the cell viability of CSP-UT. Asterisks indicate the significance of data related to EP treated vs. untreated cells. All $p$-values were obtained with Student's $t$-test by using GraphPad Prism $\left({ }^{*} p \leq 0.05 ;{ }^{* *} p \leq 0.01 ; * * * p \leq 0.001\right)$. UT: untreated cells (non-electroporated cells).

\section{Discussion}

The topic of our review is ECT, a relatively new anticancer treatment, primarily used as palliative therapy of skin metastases from different tumors. The progressive spread of ECT has led to a gradual widening of the indications for this treatment. Our group tested palliative ECT in GTs and particularly in VC, with 80\% ORR rates. Although the most 
widely used drug in combination with EP is BLM, in our systematic review, we found 10 studies on skin metastases treated with intratumoral or intravenous CSP administered with EP, with the same indications and results of BLM-based ECT. Moreover, focusing on GT only, we reviewed the literature on the in vitro and in vivo studies about CSP-based ECT, finding only three in vitro studies. All of the latter concerned ovarian cancer cells and showed promising results with this combined modality treatment. Finally, we reported the results of our in vitro study, representing the first analysis on CSP-chemoresistant squamous cells and showing that EP is able to "sensitize" cells to CSP. These results could open up new therapeutic scenarios in the treatment of VC, largely represented by squamous cell carcinomas.

VC affects old women, a heterogeneous group of patients due to several comorbidities and organ dysfunction, leading to a high demand for resources in terms of social support. Palliation of advanced and relapsing VC represents an important health and social issue. However, effective palliative treatments of VC are lacking, being the local control rates after chemotherapy relatively low and due to similar results and high toxicity rates recorded in radiotherapy series (Table S1 in Supplementary Materials). Moreover, in the available studies on VC chemotherapy and/or radiotherapy, the results in terms of QoL were generally not reported.

More specifically, the response rates achievable with different chemotherapy regimens are very low, particularly in terms of complete response with percentages ranging from $0.0 \%$ to $9.7 \%$ [57-59]. Similarly, radiotherapy results are poor, with ORRs ranging among $31.0 \%$ and $60.0 \%$, with complete response rate being $20 \%$ only, and with all patients having bulky tumors dying within 5 years [60-62]. Furthermore, radiotherapy does not appear to be an ideal treatment in the palliative setting, being associated with a non-negligible incidence and severity of AEs, able to worsening patients' quality of life. In fact, in terms of acute toxicity, the following AEs are common: mucocutaneous vulvar, perineal, and inguinal folds inflammation and potentially hematological toxicity. Moreover, in terms of late toxicity, the following AEs have been reported: teleangectasia and atrophy of skin and vulvar mucosa, dryness of vulvar and vaginal mucosa, and avascular necrosis of the femoral head [63].

In contrast, as shown by our literature review, studies on BLM-based ECT in patients with recurrent VC showed promising results in terms of symptoms relief, local control $(60-80 \%)$, and toxicity profile. Based on this evidence, the question could be: compared to BLM-based ECT, may CSP-based ECT further improve local disease control without increasing AEs rates and severity?

So far, BLM was the drug most frequently combined with ECT. However, CSP offers some theoretical advantages that should be considered. In particular, CSP may be preferred over BLM in patients with renal disease or in older patients, typically affected by impaired or at least reduced renal function. BLM is associated with higher kidney, skin, and lung toxicity and these aspects should be considered when a single patient requires multiple treatments. Moreover, the time from drug injection to EP is relatively longer with BLM (from 5 to $8 \mathrm{~min}$ ), whereas intratumorally injected CSP requires a shorter time. Regarding CSP-based ECT toxicity, considering the few studies on EP + CSP, available data on AEs are mainly related to standard chemotherapy. However, toxicity should be not relevant considering that CSP is administered only intratumorally according to the ESOPE guidelines.

The present systematic review on CSP-based ECT has several limitations. In fact, the selected studies have the following characteristics: small sample size, different treated neoplasms, retrospective design, only intralesional administration (except one), and an overall high risk of bias. However, except for one study, the authors homogeneously reported more than satisfactory results. The comparison with BLM-based ECT, particularly in terms of AEs, is also difficult considering the different administration routes, almost exclusively intravenous for BLM and intratumoral for CSP. Platinum-based compounds represent the most effective chemotherapy drugs in epithelial GTs. Literature data show 
promising results with EP combined to intratumoral administration of CSP in melanoma and other skin metastasis, but the ESOPE guidelines recommend this treatment only for lesions smaller than $3 \mathrm{~cm}$ [37]. In our previous study, we included also lesions $\geq 3 \mathrm{~cm}$, where the intralesion route in not pursuible for all VC recurrence, and IV administration seems the best solution [32]. However, the commonly used CSP may not be easy to handle in elderly patients due to the large fluid load required to prevent renal toxicity. The latter, due to tubular damage both in the acute and chronic forms, and the risk of peripheral neuropathy represent the main factors limiting the feasibility of CSP-based chemotherapy in the older population. Studies on ovarian cancer show that, compared to CSP, carboplatin has comparable efficacy with lower renal, gastrointestinal, and hematological AEs rates, with shorter duration of peripheral neuropathy. Based on this evidence, carboplatin plus paclitaxel is the preferred regimen in patients with ovarian cancer and $>75$ years old.

Regarding CSP combined to EP in GT cell models, data are very limited. Our literature review led to the identification of only three studies. However, all papers reported an improvement of CSP efficacy when combined with EP, especially in CSP resistant models. On the same wavelength, our in vitro study showed that EP is able to improve CSP effectiveness in a CSP dose-dependent manner and particularly in CSP resistant cells. Taken togheter, all these results suggest that EP could represent an efficient escamotage to bypass platinum resistance; morever, this evidence may pave the way to the translation of CSP coupled EP treatement in ovarian cancer patients who develop resistance to platinum based chemotherapy, however difficult to apply in clinical practice.

Interestingly, although $\mathrm{VC}$ is the most common cancer treated with $\mathrm{EP}$, no in vitro evaluations are reported in literature. Actually, all clinical studies in VC were directly performed in a palliative human setting and without preclinical data. Nevertheless, the recorded outcomes were excellent in most patients.

Platinum compounds are generally effective against SCC cells, but the development of chemoresistance is common. This scenario lead to the need of novel drug delivery systems to improve the efficacy of these drugs. Our in vitro study showed the possibility to improve CSP efficacy, by combination with EP, based on the viability of two cell lines, in a CSP dose-dependent manner and with a more evident effect of combined modality treatment in CSP-resistant cells. Translated into a hypothetical clinical practice, this setting could mimic VC recurrences after developement of chemoresistance where EP could be able to restore chemosensitivity.

\section{Conclusions}

Based on our and other studies, ECT with BLM is an effective and safe treatment option in the VC palliative setting. Considering the clear evidence on CSP efficacy in GTs, the chance to improve local control with CSP-based ECT is intriguing; a well designed randomized clinical trial including both drugs should be addressed to this issue, although CSP in clinical practice is more difficult to manage compared to BLM.

Supplementary Materials: The following are available online at https:/ / www.mdpi.com/article/10 .3390 / cancers13091993/s1, Table S1: Results of palliative chemotherapy and radiotherapy in vulvar carcinomas.

Author Contributions: Conceptualization: A.M.P. (Anna Myriam Perrone); Data curation and formal analysis: A.M.P. (Anna Myriam Perrone), G.R., S.M., L.A., M.T., E.D.C., M.D.S.; Investigation: A.G.M., C.Z., P.D.I., M.F., S.M., G.G. (Giulia Girolimetti); Supervision: A.G.M., P.D.I.; Writing the paper: A.M.P., G.R., L.A., A.M.P. (Anna Maria Porcelli), S.M., G.G. (Giuseppe Gasparre), F.D.T., C.Z., P.D.I. All authors reviewed the paper and approved the final draft. All authors have read and agreed to the published version of the manuscript.

Funding: In vitro study was supported by Igea Carpi Italy and partly funded by Associazione Italiana per la Ricerca sul Cancro-AIRC grant MOnARCHY IG24494 to A.M.P. (Anna Maria Porcelli). 
Institutional Review Board Statement: The study was conducted according to the guidelines of the Declaration of Helsinki and approved by the Ethics Committee of Azienda Ospedaliero-Universitaria di Bologna, Bologna, Italy. Ethics Committee code 42/2013/O/OssN.

Informed Consent Statement: Informed consent was obtained from all the subjects involved in the study.

Data Availability Statement: The data presented in this study are available on request from the corresponding author.

Conflicts of Interest: P.D.I. and A.G.M. received a grant from IGEA. Remaining authors declare no conflict of interest.

\section{References}

1. Tabbaa, Z.M.; Gonzalez, J.; Sznurkowski, J.J.; Weaver, A.L.; Mariani, A.; Cliby, W.A. Impact of the new FIGO 2009 staging classification for vulvar cancer on prognosis and stage distribution. Gynecol. Oncol. 2012, 127, 147-152. [CrossRef]

2. Weinberg, D.; Gomez-Martinez, R.A. Vulvar Cancer. Obstet. Gynecol. Clin. N. Am. 2019, 46, 125-135. [CrossRef]

3. Zapardiel, I.; Iacoponi, S.; Coronado, P.J.; Zalewski, K.; Chen, F.; Fotopoulou, C.; Dursun, P.; Kotsopoulos, I.C.; Jach, R.; Buda, A.; et al. Prognostic factors in patients with vulvar cancer: The VULCAN study. Int. J. Gynecol. Cancer 2020, 30, 1285-1291. [CrossRef] [PubMed]

4. $\quad$ Alkatout, I.; Schubert, M.; Garbrecht, N.; Weigel, M.T.; Jonat, W.; Mundhenke, C.; Günther, V. Vulvar cancer: Epidemiology, clinical presentation, and management options. Int. J. Women's Health 2015, 7, 305-313. [CrossRef] [PubMed]

5. Salom, E.M.; Penalver, M. Recurrent vulvar cancer. Curr. Treat. Options Oncol. 2002, 3, 143-153. [CrossRef] [PubMed]

6. Perrone, A.M.; Galuppi, A.; Cima, S.; Pozzati, F.; Arcelli, A.; Cortesi, A.; Procaccini, M.; Pellegrini, A.; Zamagni, C.; De Iaco, P. Electrochemotherapy can be used as palliative treatment in patients with repeated loco-regional recurrence of squamous vulvar cancer: A preliminary study. Gynecol. Oncol. 2013, 130, 550-553. [CrossRef] [PubMed]

7. Corrado, G.; Cutillo, G.; Fragomeni, S.M.; Bruno, V.; Tagliaferri, L.; Mancini, E.; Certelli, C.; Paris, I.; Vizza, E.; Scambia, G.; et al. Palliative electrochemotherapy in primary or recurrent vulvar cancer. Int. J. Gynecol. Cancer 2020, 30, 927-931. [CrossRef] [PubMed]

8. Mir, L.M.; Orlowski, S.; Belehradek, J.; Paoletti, C. Electrochemotherapy potentiation of antitumour effect of bleomycin by local electric pulses. Eur. J. Cancer Clin. Oncol. 1991, 27, 68-72. [CrossRef]

9. Ferioli, M.; Perrone, A.M.; Buwenge, M.; Arcelli, A.; Zamagni, A.; Macchia, G.; Deodato, F.; Cilla, S.; Tagliaferri, L.; De Terlizzi, F.; et al. Electrochemotherapy of skin metastases from breast cancer: A systematic review. Clin. Exp. Metastasis 2020, 38, 1-10. [CrossRef] [PubMed]

10. Sersa, G.; Miklavcic, D.; Cemazar, M.; Rudolf, Z.; Pucihar, G.; Snoj, M. Electrochemotherapy in treatment of tumours. Eur. J. Surg. Oncol. 2008, 34, 232-240. [CrossRef] [PubMed]

11. Corovic, S.; Zupanic, A.; Miklavcic, D. Numerical Modeling and Optimization of Electric Field Distribution in Subcutaneous Tumor Treated with Electrochemotherapy Using Needle Electrodes. IEEE Trans. Plasma Sci. 2008, 36, 1665. [CrossRef]

12. Probst, U.; Fuhrmann, I.; Beyer, L.; Wiggermann, P. Electrochemotherapy as a new modality in interventional oncology: A review. Technol. Cancer Res. Treat. 2018, 17, 153303381878532. [CrossRef] [PubMed]

13. Cadossi, R.; Ronchetti, M.; Cadossi, M. Locally enhanced chemotherapy by electroporation: Clinical experiences and perspective of use of electrochemotherapy. Future Oncol. 2014, 10, 877-890. [CrossRef] [PubMed]

14. Orlowski, S.; Belehradek, J.; Paoletti, C.; Mir, L.M.M. Transient electropermeabilization of cells in culture. Increase of the cytotoxicity of anticancer drugs. Biochem. Pharmacol. 1988, 37, 4727-4733. [CrossRef]

15. Esmaeili, N.; Friebe, M. Electrochemotherapy: A Review of Current Status, Alternative IGP Approaches, and Future Perspectives. J. Healthc. Eng. 2019, 2019, 2784516. [CrossRef]

16. Groselj, A.; Kos, B.; Cemazar, M.; Urbancic, J.; Kragelj, G.; Bosnjak, M.; Veberic, B.; Strojan, P.; Miklavcic, D.; Sersa, G. Coupling treatment planning with navigation system: A new technological approach in treatment of head and neck tumors by electrochemotherapy. Biomed. Eng. Online 2015, 14, S2. [CrossRef] [PubMed]

17. Campana, L.G.; Edhemovic, I.; Soden, D.; Perrone, A.M.; Scarpa, M.; Campanacci, L.; Cemazar, M.; Valpione, S.; Miklavčič, D.; Mocellin, S.; et al. Electrochemotherapy-Emerging applications technical advances, new indications, combined approaches, and multi-institutional collaboration. Eur. J. Surg. Oncol. 2019, 45, 92-102. [CrossRef] [PubMed]

18. Mir, L.M.; Glass, L.F.; Sersa, G.; Teissie, J.; Domenge, C.; Miklavcic, D.; Jaroszeski, M.J.; Orlowski, S.; Reintgen, D.S.; Rudolf, Z.; et al. Effective treatment of cutaneous and subcutaneous malignant tumours by electrochemotherapy. Br. J. Cancer 1998, 77, 2336-2342. [CrossRef] [PubMed]

19. Hofmann, G.A.; Dev, S.B.; Dimmer, S.; Nanda, G.S. Electroporation therapy: A new approach for the treatment of head and neck cancer. IEEE Trans. Biomed. Eng. 1999, 46, 752-759. [CrossRef] [PubMed]

20. Heller, R.; Jaroszeski, M.J.; Reintgen, D.S.; Puleo, C.A.; DeConti, R.C.; Gilbert, R.A.; Glass, L.F. Treatment of cutaneous and subcutaneous tumors with electrochemotherapy using intralesional bleomycin. Cancer 1998, 83, 148-157. [CrossRef] 
21. Gilbert, R.A.; Jaroszeski, M.J.; Heller, R. Novel electrode designs for electrochemotherapy. Biochim. Biophys. Acta Gen. Subj. 1997, 1334, 9-14. [CrossRef]

22. Della Latta, V.; Cecchettini, A.; Del Ry, S.; Morales, M.A.A. Bleomycin in the setting of lung fibrosis induction: From biological mechanisms to counteractions. Pharmacol. Res. 2015, 97, 122-130. [CrossRef] [PubMed]

23. Fuertes, M.; Castilla, J.; Alonso, C.; Pérez, J. Cisplatin Biochemical Mechanism of Action: From Cytotoxicity to Induction of Cell Death through Interconnections between Apoptotic and Necrotic Pathways. Curr. Med. Chem. 2012, 10, 257-266. [CrossRef] [PubMed]

24. Duan, M.; Ulibarri, J.; Liu, K.J.J.; Mao, P. Role of nucleotide excision repair in cisplatin resistance. Int. J. Mol. Sci. 2020, $21,9248$. [CrossRef]

25. Gehl, J.; Skovsgaard, T.; Mir, L.M.M. Vascular reactions to in vivo electroporation: Characterization and consequences for drug and gene delivery. Biochim. Biophys. Acta Gen. Subj. 2002, 1569, 51-58. [CrossRef]

26. Calvet, C.Y.Y.; Famin, D.; André, F.M.M.; Mir, L.M.M. Electrochemotherapy with bleomycin induces hallmarks of immunogenic cell death in murine colon cancer cells. Oncoimmunology 2014, 3. [CrossRef]

27. Calvet, C.Y.; Mir, L.M. The promising alliance of anti-cancer electrochemotherapy with immunotherapy. Cancer Metastasis Rev. 2016, 35, 165-177. [CrossRef]

28. Longo, F.; Perri, F.; Caponigro, F.; Scarpati, G.D.V.; Guida, A.; Pavone, E.; Aversa, C.; Muto, P.; Giuliano, M.; Ionna, F.; et al. Boosting the immune response with the combination of electrochemotherapy and immunotherapy: A new weapon for squamous cell carcinoma of the head and neck? Cancers 2020, 12, 2781. [CrossRef]

29. Falk, H.; Lambaa, S.; Johannesen, H.H.; Wooler, G.; Venzo, A.; Gehl, J. Electrochemotherapy and calcium electroporation inducing a systemic immune response with local and distant remission of tumors in a patient with malignant melanoma-A case report. Acta Oncol. 2017, 56, 1126-1131. [CrossRef]

30. Bellard, E.; Markelc, B.; Pelofy, S.; Le Guerroué, F.; Sersa, G.; Teissié, J.; Cemazar, M.; Golzio, M. Intravital microscopy at the single vessel level brings new insights of vascular modification mechanisms induced by electropermeabilization. J. Control. Release 2012, 163, 396-403. [CrossRef]

31. Belehradek, M.; Domenge, C.; Luboinski, B.; Orlowski, S.; Belehradek, J.; Mir, L.M.M. Electrochemotherapy, a new antitumor treatment. First clinical phase I-II trial. Cancer 1993, 72, 3694-3700. [CrossRef]

32. Perrone, A.M.; Galuppi, A.; Pirovano, C.; Borghese, G.; Covarelli, P.; De Terlizzi, F.; Ferioli, M.; Cara, S.; Morganti, A.G.; De Iaco, P. Palliative electrochemotherapy in vulvar carcinoma: Preliminary results of the ELECHTRA (electrochemotherapy vulvar cancer) multicenter study. Cancers 2019, 11, 657. [CrossRef] [PubMed]

33. Pichi, B.; Petruzzi, G.; Zocchi, J.; Pepe, G.; Moretto, S.; Manciocco, V.; Pellini, R. Response to Electrochemotherapy in a Patient with Advanced Oropharyngeal Squamous Cell Carcinoma. JAMA Otolaryngol. Head Neck Surg. 2020, 146, 1178-1179. [CrossRef] [PubMed]

34. Kunte, C.; Letulé, V.; Gehl, J.; Dahlstroem, K.; Curatolo, P.; Rotunno, R.; Muir, T.; Occhini, A.; Bertino, G.; Powell, B.; et al. Electrochemotherapy in the treatment of metastatic malignant melanoma: A prospective cohort study by InspECT. Br. J. Dermatol. 2017, 176, 1475-1485. [CrossRef] [PubMed]

35. Electrochemotherapy in the Treatment of Metastatic Malignant Melanoma: A Prospective Cohort Study by InspECT—Italian Ministry of Health. Available online: https://moh-it.pure.elsevier.com/en/publications/electrochemotherapy-in-the-treatmentof-metastatic-malignant-mela-2 (accessed on 22 March 2021).

36. Pflugfelder, A.; Kochs, C.; Blum, A.; Capellaro, M.; Czeschik, C.; Dettenborn, T.; Dill, D.; Dippel, E.; Eigentler, T.; Feyer, P.; et al. Malignant Melanoma S3-Guideline “Diagnosis, Therapy and Follow-up of Melanoma”. JDDG J. Dtsch. Dermatol. Ges. 2013, 11, 1-116. [CrossRef] [PubMed]

37. Mir, L.M.; Gehl, J.; Sersa, G.; Collins, C.G.; Garbay, J.-R.; Billard, V.; Geertsen, P.F.; Rudolf, Z.; O'sullivan, G.C.; Marty, M. Standard operating procedures of the electrochemotherapy: Instructions for the use of bleomycin or cisplatin administered either systemically or locally and electric pulses delivered by the Cliniporator TM by means of invasive or non-invasive electrodes. Eur. J. Cancer Suppl. 2006, 4, 14-25. [CrossRef]

38. Marty, M.; Sersa, G.; Garbay, J.R.; Gehl, J.; Collins, C.G.; Snoj, M.; Billard, V.; Geertsen, P.F.; Larkin, J.O.; Miklavcic, D.; et al. Electrochemotherapy-An easy, highly effective and safe treatment of cutaneous and subcutaneous metastases: Results of ESOPE (European Standard Operating Procedures of Electrochemotherapy) study. Eur. J. Cancer Suppl. 2006, 4, 3-13. [CrossRef]

39. Pellegrino, A.; Damiani, G.R.R.; Mangioni, C.; Strippoli, D.; Loverro, G.; Cappello, A.; Turoli Scd, D.; Corso, S.; Tartagni, M.; Pezzotta, M.G.G. Outcomes of Bleomycin-based electrochemotherapy in patients with repeated loco-regional recurrences of vulvar cancer. Acta Oncol. 2016, 55, 619-624. [CrossRef]

40. Perrone, A.M.; Ferioli, M.; Argnani, L.; De Terlizzi, F.; Pirovano, C.; Covarelli, P.; Dondi, G.; Ravegnini, G.; Galuppi, A.; Morganti, A.G.; et al. Quality of life In Vulvar Carcinoma treated with palliative Electrochemotherapy: The ELECHTRA (ELEctroCHemoTherapy vulvaR cAncer) Study. Cancers 2021, in press.

41. Perrone, A.M.; Ferioli, M.; Galuppi, A.; Coe, M.; De Terlizzi, F.; Tesei, M.; Dondi, G.; De Palma, A.; Morganti, A.G.; De Iaco, P. Palliative treatment with electrochemotherapy in recurrent or metastatic vaginal cancer. Int. J. Gynecol. Cancer 2020, 30, 939-946. [CrossRef] 
42. Perrone, A.M.; Cima, S.; Pozzati, F.; Frakulli, R.; Cammelli, S.; Tesei, M.; Gasparre, G.; Galuppi, A.; Morganti, A.G.; De Iaco, P. Palliative electro-chemotherapy in elderly patients with vulvar cancer: A phase II trial. J. Surg. Oncol. 2015, 112, 529-532. [CrossRef]

43. Perrone, A.M.; Galuppi, A.; Borghese, G.; Corti, B.; Ferioli, M.; Della Gatta, A.N.; Bovicelli, A.; Morganti, A.G.; De Iaco, P. Electrochemotherapy pre-treatment in primary squamous vulvar cancer. Our preliminary experience. J. Surg. Oncol. 2018, 117, 1813-1817. [CrossRef]

44. Moher, D.; Liberati, A.; Tetzlaff, J.; Altman, D.G. PRISMA Group Preferred Reporting Items for Systematic Reviews and Meta-Analyses: The PRISMA Statement. PLoS Med. 2009, 6, e1000097. [CrossRef]

45. Serša, G.; Štabuc, B.; Čemažar, M.; Jančar, B.; Miklavčič, D.; Rudolf, Z. Electrochemotherapy with cisplatin: Potentiation of local cisplatin antitumour effectiveness by application of electric pulses in cancer patients. Eur. J. Cancer 1998, 34, 1213-1218. [CrossRef]

46. Serša, G.; Štabuc, B.; Čemažar, M.; Miklavčič, D.; Rudolf, Z. Electrochemotherapy with cisplatin: The systemic antitumour effectiveness of cisplatin can be potentiated locally by the application of electric pulses in the treatment of malignant melanoma skin metastases. Melanoma Res. 2000, 10, 381-385. [CrossRef]

47. Sersa, G.; Stabuc, B.; Cemazar, M.; Miklavcic, D.; Rudolf, Z. Electrochemotherapy with Cisplatin: Clinical Experience in Malignant Melanoma Patients. Clin. Cancer Res. 2000, 6, 863-867. [PubMed]

48. Hribernik, A.; Cemazar, M.; Sersa, G.; Bosnjak, M.; Snoj, M. Effectiveness of electrochemotherapy after IFN- $\alpha$ adjuvant therapy of melanoma patients. Radiol. Oncol. 2016, 50, 21-27. [CrossRef] [PubMed]

49. Snoj, M.; Rudolf, Z.; Cemazar, M.; Jancar, B.; Sersa, G. Successful sphincter-saving treatment of anorectal malignant melanoma with electrochemotherapy, local excision and adjuvant brachytherapy. Anticancer Drugs 2005, 16, 345-348. [CrossRef]

50. De Giorgi, V.; Scarfi, F.; Covarelli, P. Electrochemotherapy with intralesional cisplatin in recurrent or metastatic vulvar cancer. Int. J. Gynecol. Cancer 2020, 30, 1469. [CrossRef] [PubMed]

51. Rebersek, M.; Cufer, T.; Cemazar, M.; Kranjc, S.; Sersa, G. Electrochemotherapy with cisplatin of cutaneous tumor lesions in breast cancer. Anticancer Drugs 2004, 15, 593-597. [CrossRef] [PubMed]

52. Gregor, S.; Maja, C.; Zvonimir, R. Electrochemotherapy: Advantages and drawbacks in treatment of cancer patients. Cancer Ther. 2003, 1, 133-142.

53. Campana, L.G.G.; Mali, B.; Sersa, G.; Valpione, S.; Giorgi, C.A.A.; Strojan, P.; Miklavcic, D.; Rossi, C.R.R. Electrochemotherapy in non-melanoma head and neck cancers: A retrospective analysis of the treated cases. Br. J. Oral Maxillofac. Surg. 2014, 52, 957-964. [CrossRef] [PubMed]

54. Cemazar, M.; Sersa, G.; Miklavcic, D. Electrochemotherapy with cisplatin in the treatment of tumor cells resistant to cisplatin. Anticancer Res. 1998, 18, 4463-4466. [PubMed]

55. Saczko, J.; Kamińska, I.; Kotulska, M.; Bar, J.; Choromańska, A.; Rembiałkowska, N.; Biezuńska-Kusiak, K.; Rossowska, J.; Nowakowska, D.; Kulbacka, J. Combination of therapy with 5-fluorouracil and cisplatin with electroporation in human ovarian carcinoma model in vitro. Biomed. Pharmacother. 2014, 68, 573-580. [CrossRef]

56. Łapińska, Z.; Dębiński, M.; Szewczyk, A.; Choromańska, A.; Kulbacka, J.; Saczko, J. Electrochemotherapy with calcium chloride and 17 $\beta$-estradiol modulated viability and apoptosis pathway in human ovarian cancer. Pharmaceutics 2021, 13, 19. [CrossRef]

57. Wagenaar, H.C.; Colombo, N.; Vergote, I.; Hoctin-Boes, G.; Zanetta, G.; Pecorelli, S.; Lacave, A.J.; Van Hoesel, Q.; Cervantes, A.; Bolis, G.; et al. Bleomycin, methotrexate, and CCNU in locally advanced or recurrent, inoperable, squamous-cell carcinoma of the vulva: An EORTC gynaecological cancer cooperative group study. Gynecol. Oncol. 2001, 81, 348-354. [CrossRef] [PubMed]

58. Durrant, K.R.; Mangioni, C.; Lacave, A.J.; George, M.; van der Burg, M.E.L.; Guthrie, D.; Rotmenz, N.; Dalesio, O.; Vermorken, J.B. Bleomycin, methotrexate, and CCNU in advanced inoperable squamous cell carcinoma of the vulva: A phase II study of the EORTC gynaecological cancer cooperative group (GCCG). Gynecol. Oncol. 1990, 37, 359-362. [CrossRef]

59. Benedetti-Panici, P.; Greggi, S.; Scambia, G.; Salerno, G.; Mancuso, S. Cisplatin (P), bleomycin (B), and methotrexate (M) preoperative chemotherapy in locally advanced vulvar carcinoma. Gynecol. Oncol. 1993, 50, 49-53. [CrossRef]

60. Prempree, T.; Amornmarn, R. Radiation treatment of recurrent carcinoma of the vulva. Cancer 1984, 54, 1943-1949. [CrossRef]

61. Tewari, K.; Cappuccini, F.; Syed, A.M.N.; Puthawala, A.; DiSaia, P.J.; Berman, M.L.; Manetta, A.; Monk, B.J. Interstitial brachytherapy in the treatment of advanced and recurrent vulvar cancer. Am. J. Obstet. Gynecol. 1999, 181, 91-98. [CrossRef]

62. Hruby, G.; MacLeod, C.; Firth, I. Radiation treatment in recurrent squamous cell cancer of the vulva. Int. J. Radiat. Oncol. Biol. Phys. 2000, 46, 1193-1197. [CrossRef]

63. Chino, J.; Havrilesky, L.; Montana, G. Carcinoma of the vulva. In Perez and Brady's Principles and Practices of Radiation Oncology; Lippincott Williams and Wilkins: London, UK, 2013; pp. 1502-1516. 